\title{
DFT Calculation on the Electron Affinity of Polychlorinated Dibenzo-p-dioxins
}

\author{
Jung Eun Lee, Wonyong Choi, ${ }^{*}$ and Bỵung Jin Mhin ${ }^{\dagger * *}$
}

\author{
School of Emirommental Science and Engineering, Pohang Lnwersin of Science and Technologv. Pohang 790-784, Korea \\ 'Deparment of Chemistrv. PalChai Chiversit, +93-6 Doma-dong, Seoku, Daejeon $302-735$, Korea
}

Received March 1+.2003

\begin{abstract}
Polychlorinated dibenzo-p-dioxins (PCDDs) are extremely toxic and persistent environmental pollutants. Their chemical reactivities and other physicochemical/biological properties show a strong dependence on the chlorination pattern. With increasing the number of chlorines dioxin congeners become more electronegative and gain higher electron affinities. The vertical electron affinities (VEA) are related with the LUMO energies of neutral molecules. LUMO energies of all PCDD congeners were calculated at the B3LYP/6-3IG** level and those of some selected congeners at the level of B3LYP/6-311 G**/B3LYP/6-31 G** and B3LYP/cc-pvtz/ /B3LYP/6-31G**. The total energies of neutral and anionic species for dibenzo-p-dioxins (DD). 1469-TCDD. 2378-TCDD. and OCDD were calculated at the level of B3LYP/6-31G**. B3LYP/aug-cc-pvdz, and B3LYP/ aug-cc-pvtz/B3LYP/6-3IG**. By using the four congeners with $\mathrm{D}_{21,}$ symmetry as reference molecules. we could estimate VEA (B3LYP/aug-cc-pvdz) of 75 PCDD congeners based on the linear correlations between LUMO energy and VEA (B3LYP/6-31 $\mathrm{G}^{* *}$ ) and between VEA (B3LYP/6-3IG**) and VEA (B3LYP/aug-ccpvtz/B3LYP/6-3IG**). Results show that all PCDDs with the number of $\mathrm{Cl} \geq 3$ have positive electron affinities. The PCDD electron affinity values provided in this work can be a useful data set in understanding the congener-specific reactivities of dioxins in various environmental media.
\end{abstract}

Key Words : Polychlorinated dibenzo-p-dioxin, DFT, Electron affinity

\section{Introduction}

Polychlorinated dibenzo-p-dioxins (PCDDs) have attracted public interests due to their toxicity and persistency. ${ }^{1.2} \mathrm{~A}$ large quantity of PCDDs has been emitted into the atmosphere from various incineration sources of chlorinecontaining wastes. ${ }^{3 \cdot 6}$ transported through a long distance. and distributed globally. ${ }^{7.9}$ PCDDs have very low water solubility and accunulate in lipids of biological organisms.

Physical, chemical, and biological properties of PCDDs strongly depend on the number and position of substituted chlorines in general. In particular. it is widely recognized that the biological toxicities of PCDDs are extremely congener specific. ${ }^{10,11}$ Recently, Mhin et al. ${ }^{12}$ have shown that the molecular quadrupole moments as a surrogate parameter for molecular charge distribution change sensitively and systematically with the chlorination pattern and that all toxic congeners share a unique charge distribution pattern. The ring vibrational IR frequencies of PCDDs are also very sensitive to the chlorination pattern. ${ }^{13}$ Lee et $a .^{14}$ recently calculated the heat of formation for 75 PCDD congeners using a DFT method and demonstrated that the intramolecular cllorine repulsion energies critically affect their thermodynamic properties in a systematic way. While many other physicochemical properties of PCDDs are expected to be highly congener-specific. experimental data on PCDDs are scarce due to their toxicity and experimental difficulties in dealing with them. ${ }^{15.17}$ Therefore, computational methods are ideal for predicting their properties and in other dioxin-

\footnotetext{
"To whom correspondence should be addressed E-mail: wchoia' postech.ac.kr; mhing mail.pcuac.kr
}

related research. ${ }^{18 \cdot-1}$

Frontier orbitals and the gap energy between HOMO and LUMO can be employed to explain reactivities of PCDDs as well as their themodynamic properties. ${ }^{19.23}$ Koester et $\mathrm{al}^{19}{ }^{19}$ reported MNDO calculation results for LUMO energies of PCDDs with the number of $\mathrm{Cl} \geq 4$. However. semi-empirical calculations on electronic properties such as an electron affinity are not reliable. Berkout et $a l^{l^{4-1}}$ reported that an electron attachment energy obtained from electron capture negative ion mass spectrometry was well correlated with the virtual orbital energy calculated at DFT level. In a previous study. ${ }^{25}$ the electronic energy required for the transition from a neutral ground state to a lowest excited anionic state was assumed to be a vertical electronic affinity (VEA). They calculated VEA of 1368-TCDD, 2378-TCDD. and 1234 TCDD at the level of B3LYP/aug'-cc-pvdz to be 0.232 , 0.152 , and $0.116 \mathrm{eV}$, respectively. DFT calculation gave reasonable estimations for VEA

In this work, we carried out DFT calculation to estimate VEA for all 75 PCDD congeners by using the calculated vertical electron affinities of highly symmetric congeners as references: dibenzo- $p$-dioxin (DD), 1,4,6.9-tetrachlorinated dibenzo-p-dioxin (1469-TCDD), 2,3.7,8-tetrachlorinated dibenzo-p-dioxin (2378-TCDD), and octaclulorinated dibenzo$p$-dioxin (OCDD). The calculated results show that monoand some dicllorinated dioxins have negative electron affinities while all other congeners with the number of $\mathrm{Cl} \geq 3$ have positive electron affunities.

\section{Computational Methods}

We have carried out DFT calculation using a Gaussian 98 
<smiles>c1ccc2c(c1)Oc1ccccc1O2</smiles>
DD<smiles>Clc1ccc(Cl)c2c1Oc1c(Cl)ccc(Cl)c1O2</smiles>

1469-TCDD

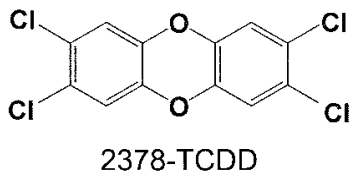<smiles>O=C([O-])Oc1c(Cl)c(Cl)c(Cl)c(Cl)c1Cl</smiles>

Scheme 1. Structure of four diosin congeners with $D_{2 h}$ symmetry for which the vertical electron aftinities (VEA) were directly calculated in this work.

suit of programs $\mathrm{s}^{-6}$ for DD and 75 PCDDs at the B3LYP/6$31 \mathrm{G}^{* *}$ level to obtain their LUMO energies. Vertical electron affinities (VEA) were obtained for DD, 1469-TCDD, 2378TCDD. OCDD (Scheme 1) based upon the calculation for the neutral and anionic species at the level of B3LYP/6$31 \mathrm{G}^{* *}$. B3LYP/aug-cc-prdz. and B3LYP/aug-cc-pvtz// $\mathrm{B} 3 \mathrm{LYP} / 6-31 \mathrm{G}^{* *}$. VEA ${ }^{-5}$ was evaluated from eq 1 :

$$
\operatorname{VEA}(\mathrm{eV})=E_{\text {nеuтral }}-E_{\text {anın }}
$$

where $E_{\text {neutral }}$ is the total energy of neutral dioxin species at an optimized geometry and $E_{\text {anion }}$ is the total energy of the corresponding dioxin anion calculated at the optimized geometry of the neutral species. DFT calculation for openshell sy'stems such as the anionic species reduces spin contamination. ${ }^{27.28}$ MP2 level calculation was not performed due to spin contamination. In our calculation the $\mathrm{S}^{2}$ value for anionic radical value is less than 0.76

\section{Results and Discussion}

The total energies of neutral and anionic species for DD. 1469-TCDD 2378-TCDD. and OCDD are calculated at the level of B3LYP/6-31G**. B3LYP/aug-cc-pvdz. and B3LYP/ aug-cc-pvtz/B3LYP/6-31 G** are listed in Table 1. Based on the total electronic energies of neutral and anionic dioxin species. VEA for the four $\mathrm{D}_{\mathrm{s} h}$ congeners are obtained from eq 1. The nuclear geometry of anions is assumed to be the same to that of neutral dioxin molecules. It was reported that VEA values calculated at the DFT level was reliable and consistent with experimental results: the previously reported VEA value of 1234-TCDD calculated at the B3LYP/aug'-cc- pvdz level was $0.116 \mathrm{eV}^{25}$ which is agreeable with the experimental value of $0.11 \mathrm{eV}^{24}$

LUMO energies of DD and 75 PCDDs calculated at the B3LYP/6-31G** level are listed in Table 2. LUMO energies calculated using different basis sets are compared in Figure 1. which shows that they monotonously decrease with increasing the number of chlorines. DD has the highest LUMO energy and OCDD, the lowest among all. Electron affinity is proportional to negative LUMO energy: We obtain good linear correlations between LUMO and VEA at the B3LYP/6-31G** $\left(\mathrm{R}^{2}=0.9960\right)$, the B3LYP/aug-cc-pvdz. $\left(\mathrm{R}^{2}=0.9906\right)$ and B3LYP/aug-cc-pvtz//B3LYP/6-31 G** $\left(\mathrm{R}^{2}\right.$ $=0.9664$ ) level as shown in Figure 2. LUMO and VEA at the B3LYP/6-31G**. B3LYP/aug-cc-pvdz. and B3LYP/aug-ccprtz/B3LYP/6-31G** level can be related through eqs 2. 3. and 4 , respectively.

$$
\begin{aligned}
& \text { VEA (B3LYP/6-31G**) }=-1.953-38.211 E_{\text {LtMo }} \\
& \text { VEA (B3LYP/aug-cc-pvdz) }=-0.685-19.018 E_{\text {LLMO }} \\
& \text { VEA (B3LYP/aug-cc-pttz/B3LYP/6-31G**) } \\
& \quad-0.623-19.099 E_{\mathrm{LLNO}}
\end{aligned}
$$

We performed similar calculations at the level of B3LYP/ aug-cc-pvdz and B3LYP/aug-cc-pvtz/B3LYP/6-31G** for

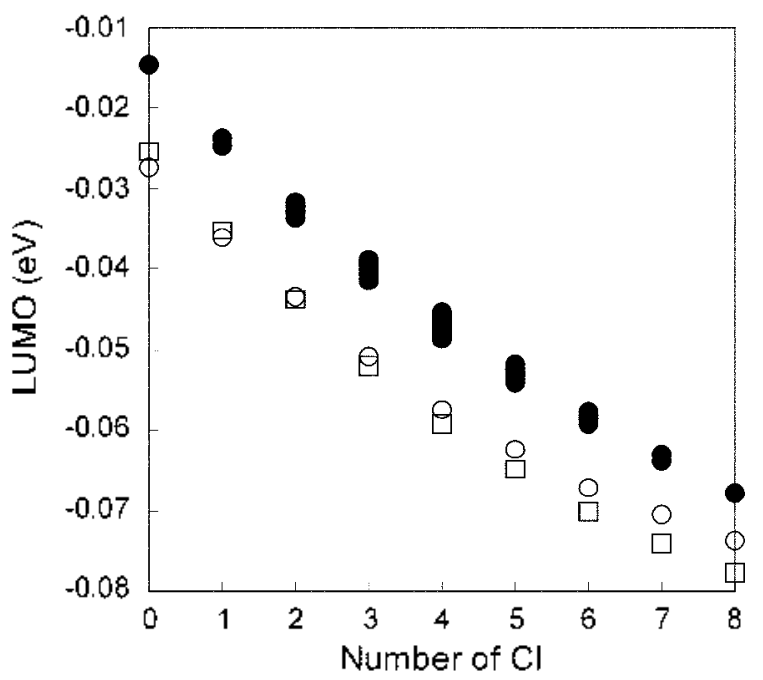

Figure 1. LUMO energies of PCDDs calculated at the level of B3LYP/6-3IG** (filled circle) for all congeners, B3LYP/cc-pvtz// B3LYP/6-31G** (open circle), and B3LYP/6-311G**/B3LYP/6$31 G^{* *}$ (open square) for the most stable congeners within the

\begin{tabular}{|c|c|c|c|c|c|c|c|c|c|}
\hline & \multicolumn{3}{|c|}{ B3LYP/6-31G** } & \multicolumn{3}{|c|}{ B3LYP/allg-cc-pvdz } & \multicolumn{3}{|c|}{ B3LYP/aug-cc-pvtz//B3LYP/6-31G** } \\
\hline & Neutral & Anion & VEA & Neutral & Anion & VEA & Nelutral & Anion & VEA \\
\hline $\mathrm{DD}$ & -612.54018 & -612.48758 & -1.431 & -612.59925 & -612.58510 & -0.385 & -612.74844 & -612.73765 & -0.294 \\
\hline 2378-TCDD & -2450.90069 & -2450.89710 & -0.098 & -2451.06196 & -2451.06772 & 0.157 & -2451.25833 & -2451.26656 & 0.224 \\
\hline 1469-TCDD & -2450.89662 & -2450.89240 & -0.115 & -2451.05704 & -2451.06465 & 0.207 & -2451.25564 & -2451.26288 & 0.197 \\
\hline OCDD & -4289.23236 & -4289.25368 & 0.580 & -4289.49543 & -4289.51893 & 0.640 & -4289.74513 & -4289.77276 & 0.752 \\
\hline
\end{tabular}
homologues (DD, 2-MCDD, 27-DCDD, 137-TrCDD, 1369TCDD, 12479-PCDD, 124689-HxCDD, 1234679-HpCDD, OCDD).

Table 1. Total Energies (Hartrej) of Nentral and Anionic Dioxin Species and VEA (eV) Calculated at the level of B3LYP/6-31G**. B3LYP/ aug-cc-pvdz, and B 3 LYP/aug-cc-pvtz/B3LYP/6-3IG** 
Table 2. Calculated Total Energy ( $\left.E_{\text {(ct }}\right)^{\prime \prime}$ (Hartree), -LUMO (eV) at the B3LYP/6-31 $\mathrm{G}^{* *}$, and VEA (eV) ${ }^{c . d}$ Estimated at the Level of B3LYP/aug-cc-pvdz and B3LYP/aug-cc-pvtz/B3LYP/6-3IG** for PCDDs

\begin{tabular}{|c|c|c|c|c|}
\hline & $E_{\mathrm{tmt}}{ }^{a}$ & - LUMO $^{b}$ & $\mathrm{VEA}^{\prime}$ & $\mathrm{VEA}^{d}$ \\
\hline & $\begin{array}{c}\mathrm{B} 3 \mathrm{LYP} / 6- \\
31 \mathrm{G}^{* *}\end{array}$ & $\begin{array}{l}\text { B3LYP/ } \\
6-31 G^{* *}\end{array}$ & $\begin{array}{c}\text { B3LYP } \\
\text { faug-cc- } \\
\text { prodz }\end{array}$ & $\begin{array}{c}\text { B3LYP/aug- } \\
\text { cc-pvtz } \\
\text { /B3LYP/6- } \\
31 \mathrm{G}^{* *}\end{array}$ \\
\hline $\mathrm{DD}$ & -612.54018 & 0.015 & -0.403 & -0.336 \\
\hline 2-MCDD & -1072.13315 & 0.025 & -0.215 & -0.149 \\
\hline 1-MCDD & -1072.13034 & 0.024 & -0.232 & -0.166 \\
\hline 27-DCDD & -1531.72563 & 0.034 & -0.044 & 0.022 \\
\hline 28-DCDD & -1531.72563 & 0.034 & -0.044 & 0.022 \\
\hline 17-DCDD & -1531.72290 & 0.033 & -0.059 & 0.007 \\
\hline 18-DCDD & -1531.72280 & 0.033 & -0.060 & 0.006 \\
\hline 13-DCDD & -1531.72191 & 0.033 & -0.056 & 0.010 \\
\hline 23-DCDD & -1531.72104 & 0.032 & -0.070 & -0.004 \\
\hline 16-DCDD & -1531.72021 & 0.032 & -0.074 & -0.008 \\
\hline 14-DCDD & -1531.71960 & 0.032 & -0.066 & 0.000 \\
\hline 19-DCDD & -1531.71956 & 0.032 & -0.082 & -0.016 \\
\hline 12-DCDD & -1531.71836 & 0.032 & -0.084 & -0.018 \\
\hline $137-\mathrm{TrCDD}$ & -1991.31407 & 0.041 & 0.104 & 0.169 \\
\hline 138-TrCDD & -1991.31405 & 0.041 & 0.102 & 0.168 \\
\hline $237-\mathrm{TrCDD}$ & -1991.31327 & 0.041 & 0.089 & 0.155 \\
\hline 147-TrCDD & -1991.31176 & 0.041 & 0.093 & 0.159 \\
\hline 136-TrCDD & -1991.31138 & 0.041 & 0.089 & 0.154 \\
\hline 139-TrCDD & -1991.31083 & 0.040 & 0.082 & 0.148 \\
\hline $127-\mathrm{TrCDD}$ & -1991.31063 & 0.040 & 0.076 & 0.142 \\
\hline 128-TrCDD & -1991.31053 & 0.040 & 0.076 & 0.141 \\
\hline 178-TrCDD & -1991.31050 & 0.040 & 0.074 & 0.140 \\
\hline 146-TrCDD & -1991.30851 & 0.040 & 0.073 & 0.138 \\
\hline 126-TrCDD & -1991.30798 & 0.039 & 0.063 & 0.128 \\
\hline $129-\mathrm{TrCDD}$ & -1991.30729 & 0.039 & 0.055 & 0.120 \\
\hline $124-\mathrm{TrCDD}$ & -1991.30646 & 0.040 & $0.07 \hat{3}$ & 0.139 \\
\hline $123-\mathrm{TrCDD}$ & -1991.30502 & 0.039 & 0.055 & 0.120 \\
\hline 1368-TCDD & -2450.90225 & 0.049 & 0.239 & 0.304 \\
\hline 1379-TCDD & -2450.90181 & 0.048 & 0.234 & 0.299 \\
\hline 1378-TCDD & -2450.90145 & 0.048 & 0.225 & 0.290 \\
\hline 2378-TCDD & -2450.90069 & 0.047 & 0.212 & 0.277 \\
\hline 1369-TCDD & -2450.89942 & 0.048 & 0.225 & 0.290 \\
\hline 1478-TCDD & -2450.89911 & 0.047 & 0.216 & 0.281 \\
\hline 1268-TCDD & -2450.89889 & 0.047 & 0.215 & 0.280 \\
\hline $1247-\mathrm{TCDD}$ & -2450.89849 & 0.048 & 0.222 & 0.287 \\
\hline 1248-TCDD & -2450.89841 & 0.048 & 0.222 & 0.287 \\
\hline 1279-TCDD & -2450.89837 & 0.047 & 0.207 & 0.273 \\
\hline 1278-TCDD & -2450.89801 & 0.047 & 0.200 & 0.265 \\
\hline 1237-TCDD & -2450.89702 & 0.047 & 0.204 & 0.269 \\
\hline 1238-TCDD & -2450.89699 & 0.047 & 0.203 & 0.268 \\
\hline 1469-TCDD & -2450.89662 & 0.047 & 0.210 & 0.275 \\
\hline 1269-TCDD & -2450.89605 & 0.047 & 0.199 & 0.265 \\
\hline $1267-\mathrm{TCDD}$ & -2450.89559 & 0.046 & 0.189 & 0.255 \\
\hline 1249-TCDD & -2450.89518 & 0.047 & 0.202 & 0.267 \\
\hline $1246-\mathrm{TCDD}$ & -2450.89517 & 0.047 & $0.20 \hat{3}$ & 0.268 \\
\hline 1289-TCDD & -2450.89486 & 0.046 & 0.182 & 0.247 \\
\hline $1236-\mathrm{TCDD}$ & -2450.89435 & 0.046 & 0.190 & 0.255 \\
\hline
\end{tabular}

Table 2. Continued.

\begin{tabular}{|c|c|c|c|c|}
\hline & $\mathrm{E}_{\mathrm{cut}}{ }^{\circ}$ & - LUMO $^{b}$ & $\mathrm{VEA}^{\circ}$ & $\mathrm{VEA}^{\prime} d$ \\
\hline & $\begin{array}{c}\text { B3LYP/6- } \\
31 \mathrm{G}^{* *}\end{array}$ & $\begin{array}{l}\text { B3LYP/ } \\
6-31 \mathrm{G}^{* *}\end{array}$ & $\begin{array}{c}\text { BiLYP } \\
\text { /allo-ce- } \\
\text { pvdz }\end{array}$ & $\begin{array}{c}\text { B3LYP/alug- } \\
\text { cc-pvtz } \\
\text { /B3LYP/6- } \\
31 \mathrm{G}^{* *}\end{array}$ \\
\hline 1239-TCDD & -2450.89376 & 0.046 & 0.183 & 0.249 \\
\hline 1234-TCDD & -2450.88835 & 0.045 & 0.178 & 0.243 \\
\hline 12479-PCDD & -2910.48591 & 0.054 & 0.343 & 0.408 \\
\hline 12468-PCDD & -2910.48586 & 0.054 & 0.344 & 0.409 \\
\hline 12478-PCDD & -2910.48558 & 0.054 & 0.336 & 0.400 \\
\hline 12368-PCDD & -2910.48498 & 0.054 & 0.331 & 0.396 \\
\hline 12379-PCDD & -2910.48456 & 0.053 & 0.325 & 0.390 \\
\hline 12378-PCDD & -2910.48422 & 0.053 & 0.318 & 0.383 \\
\hline 12469-PCDD & -2910.48306 & 0.053 & 0.330 & 0.395 \\
\hline 12467-PCDD & -2910.48262 & 0.053 & 0.320 & 0.385 \\
\hline 12489-PCDD & -2910.48250 & 0.053 & 0.320 & 0.385 \\
\hline 12369-PCDD & -2910.48225 & 0.053 & 0.321 & 0.386 \\
\hline 12367-PCDD & -2910.48168 & 0.052 & 0.308 & 0.373 \\
\hline 12389-PCDD & -2910.48115 & 0.052 & 0.301 & 0.366 \\
\hline 12347-PCDD & -2910.48011 & 0.053 & 0.317 & 0.382 \\
\hline 12346-PCDD & -2910.47689 & 0.052 & 0.299 & 0.364 \\
\hline 124689-HxCDD & -3370.06947 & 0.059 & 0.442 & 0.506 \\
\hline 124679-HxCDD & -3370.06945 & 0.059 & 0.441 & 0.506 \\
\hline 123679-HxCDD & -3370.06860 & 0.059 & 0.429 & 0.494 \\
\hline $123689-\mathrm{H} \times \mathrm{CDD}$ & -3370.06854 & 0.059 & 0.429 & 0.493 \\
\hline 123678-HxCDD & -3370.06774 & 0.058 & 0.417 & 0.482 \\
\hline $123468-\mathrm{H} \times \mathrm{CDD}$ & -3370.06752 & 0.059 & 0.431 & 0.496 \\
\hline 123789-HxCDD & -3370.06725 & 0.058 & 0.412 & 0.476 \\
\hline 123478-HxCDD & -3370.06714 & 0.058 & 0.424 & 0.489 \\
\hline 123469-HxCDD & -3370.06471 & 0.058 & 0.418 & 0.483 \\
\hline $123467-\mathrm{H} \times \mathrm{CDD}$ & -3370.06415 & 0.058 & 0.409 & 0.474 \\
\hline 1234679-HpCDD & -3829.65089 & 0.064 & 0.523 & 0.588 \\
\hline 1234678-HpCDD & -3829.65007 & 0.063 & 0.511 & 0.576 \\
\hline OCDD & -4289.23236 & 0.068 & 0.599 & 0.664 \\
\hline
\end{tabular}

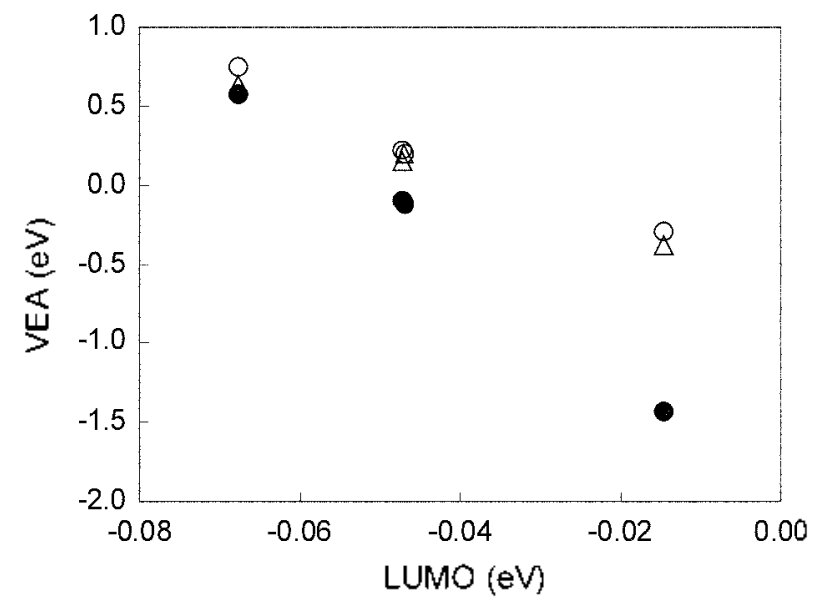

Figure 2. Correlation between LUMO calculated at the B.LYP/6$31 G^{* *}$ level and VEA (B3LYP/6-3IG**) (filled circle) VEA (B3LYP/aug-cc-pvdz) (open triangle), and VEA (B3LYP/aug-ccpvtz//B3LYP/6-31 *** $^{*}$ ) (open circle) for DD, 1469-TCDD, 2378TCDD, OCDD. 


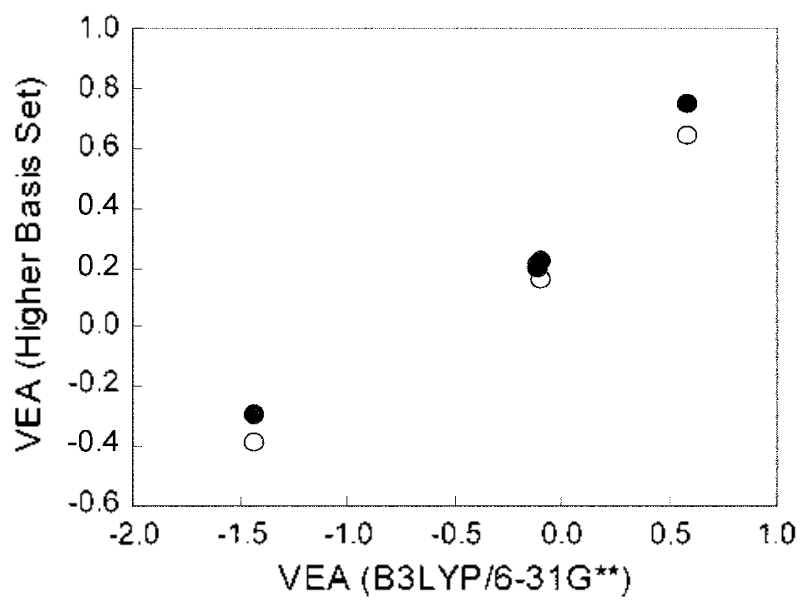

Figure 3. Correlation between VEA (B3LYP/6-31G**) and VEA (B3LYP/aug-cc-pvdz) (open symbol) or VEA (B3LYP/aug-ccpytz/B3LYP/6-3IG**) (tilled symbol) for DD, 1469-TCDD, 2378-TCDD, OCDD

$D_{\text {sh }}$ congeners to get more reliable electron affinities. which are listed in Table 1. VEA calculated at the B3LYP/6-31G** level are well correlated with VEA obtained at the B3LYP/ aug-cc-pvdz level and B3LYP/aug-cc-pvtz/B3LYP/6$31 \mathrm{G}^{* *}$ for $\mathrm{D}_{\text {sh }}$ congeners as shown in Figure 3 . The linear relation between these two VEA values can be represented by eq 5 and eq 6 . respectively.

$$
\begin{aligned}
& \text { VEA (B3LYP/aug-cc-pvdz) }=0.286+0.493 \text { VEA } \\
& \left(B 3 L Y P / 6-31 \mathrm{G}^{* *}\right)\left(\mathrm{R}^{2}=0.976\right) \\
& \text { VEA }(\mathrm{B} 3 \mathrm{LYP} / \text { aug-cc-pvtz/B3LYP/6-31G**) } \\
& \quad=0.351+0.492 \mathrm{VEA}\left(\mathrm{B} 3 \mathrm{LYP} / 6-31 \mathrm{G}^{* *}\right)\left(\mathrm{R}^{2}=0.940\right)
\end{aligned}
$$

We estimate VEA values for all PCDD congeners by using eqs 5 and 6 , which are also listed in Table 2 . The experimental electron attachunent energies obtained from electron capture negative ion mass spectrometry were 0.11 and 0.2 $\mathrm{eV}$ for 1234-TCDD and 12378-PCDD, respectively ${ }^{-1}$ which could be compared with the estimated electron affinities. VEA $(1234-T C D D)=0.178 \mathrm{eV}$ and VEA $(12378-P C D D)=$ $0.318 \mathrm{eV}$ in Table 2 .

Figure 4 shows the variation of the estimated VEA (B3LYP/aug-cc-pvtz/B3LYP/6-31 $\mathrm{G}^{* *}$ ) as a function of $\mathrm{Cl}$ numbers. VEA steadily increases with the number of chlorines. On the other hand dioxin congeners with the same number of chlorines are all similar in their VEA values (i.e., no position effect). It is compared with the fact that molecular charge distribution and IR frequencies of dioxins are highly sensitive to the position of substituted chlorines. ${ }^{12.13}$ The difference between VEA (B3LYP/aug-ccpvdz) and VEA (B3LYP/6-31 $\mathrm{G}^{* *}$ ) in Table 1 is $1.046 \mathrm{eV}$ for DD. but only $0.060 \mathrm{eV}$ for OCDD. which indicates that VEA values calculated from small and large basis sets converge with increasing the chlorine numbers. PCDDs with the number of $\mathrm{Cl} \geq 3$ have positive VEA whereas DD. MCDD, and DCDD congeners show negative VEA values.

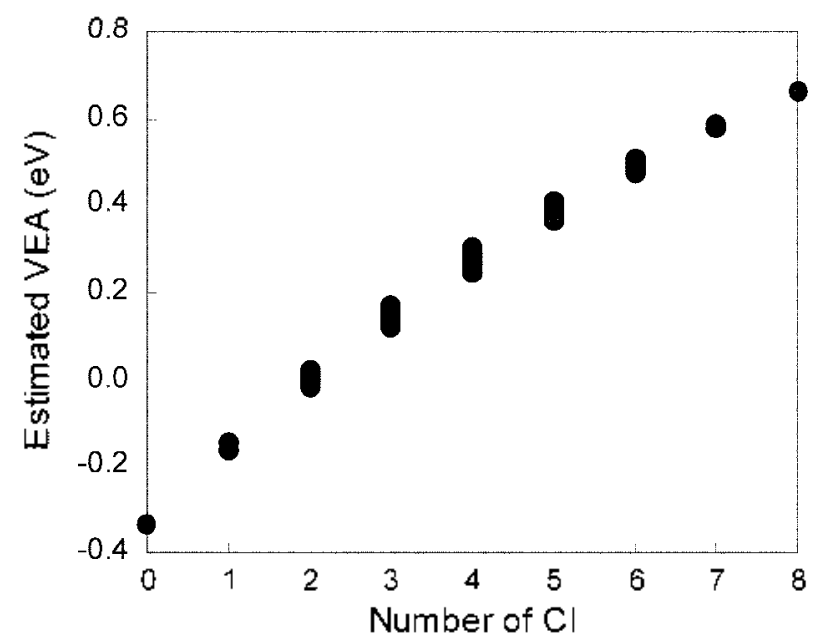

Figure 4. Estimated VEA (B3LYP/aug-ce-pvtz/B3LYP/6-31G**) of PCDDs as a function of $\mathrm{C} l$ numbers.

Therefore, anionic forms of highly chlorinated congeners are energetically more stable than neutral species.

Molecules carrying higher EA could be more reactive under reductive conditions. The chenical and biological reactivities of highly chlorinated dioxin congeners in various environmental media should be dependent on the electron donating tendency of the surrounding media. ${ }^{2-31}$ For example. the photolytic degradation of OCDD in organic solvent was markedly enlanced in the presence of triethylamine (TEA) ${ }^{32}$ In photolytic degradation of halogenated aromatic compounds ${ }^{33.34}$ TEA can play the role of an electron donor to form an excited charge-transfer complex upon photon absorption and induce the formation of anionic species. In general, excited anionic species as an intermediate could be involved in the photolytic degradation of PCDDs in reductive media. Therefore the vertical electron affinities calculated in this work could be valuable in understanding the congener-specific reactivities of PCDDs and their fate in environmental media.

Acknowledgment. This work was supported by the Korea Science and Engineering Foundation (Grant No. R-14-2002004-01001-0) and partly by the Brain Korea 21 project.

\section{References}

1. Chlorinated Dioxins and Dibenzofurats in the Total Enmiromtent Choudhary. G.. Keith. L. H.. Rappe. C.. Eds.: Butterworth Publishers: Boston1. 1983.

2. Dioxin and Healtr: Schecter. A.. Ed.: Plenlum Press: New York. U. S. A.. 1994.

3. Olie. K.: Vermeulen, P. L.: Hutzinger. O. Chemosphere 1977, 6. 455.

4. Bacher. R: Swerev. M.: Ballschmiter. B. Enwiron. Sci. Techol. 1992. 26. 1649.

5. Additlk. R.: Govers. H. A. T.: Olie. K. Enniron. Sci. Techol. 1998. 32. 1888 .

6. Yasuhara, A:; Katami. T.: Okuda, T:; Ohno, N.: Shibamoto, T. Eniron. Sci. Techol 2001, 35, 1373.

7. Brubaker. W. W.: Hites. R. A. J. Phys. Chem .A 1998. 102.915. 
8. Athinson. R. In Isstes in Enirommental Science and Technology: Hester. R. E.. Harrison. R. M.. Eds.: The Royal Society of Chemistry: Cambridge. U.K. 1996: Vol. 6.p 53

9. Baker. J. I.: Hites. R. A. Efniron. Sci. Technol. 2000. 3f. 2879.

10. Safe, S. Crit Rev Toricol 1990.21 .51$.

11. Mason, G.: Farrell, K.: Kers, B.: Piskorska-Pliszezynska, J.; Safe. L.: Safe, S. Toxicology 1986, 41,21 .

12. Mhin. B. J.: Lee. J. E.: Choi, W. J. Am. (Chem. Soc. 2002. 124. 144.

13. Mhin. B. J.: Choi, J.: Choi. W. J. Am. Chem. Soc. 2001, 123.3584.

14. Lee, J. E.: Choi. W.: Mhin. B. I. J. Phus Chem at 2003. 107. 2693.

15. Choi, W. Hong. S. J. Chang, Y.S. Cho, Y. Eniron Sci Technol. 2000. 34.4810

16. Kwok. E. S. C.: Arey. J.: Atkinson. R. Emifon. Sci. Techmol. 1994. 28.528.

17. Addink. R.: Olie. K. Eminon. Sci. Techol. 1995. 29, 1425.

18. Huang, C.-L.; Harrison. B. K: Madura. I.: Dolfing. I. Envin. Toricol Chent 1996. 15,824.

19. Koester C. I.: Hites, R. A. Chemosphere 1988, 17. 2355.

20. Saito. N.: Fuwa. A. Chemosphere 2000. 40.131.

21. Unsworth. J. F.: Dorans. H. Chemosphere 1993. 27. 351.

22. Lynam. M. M.: Kuty. M.: Damborsky, J.: Koca. J.: Adriaens. P. Eniron. Toxicol Chent 1998.17,988.

23. Cheney, B. V: Tolly T. Int. J. Otwanth Chem. 1979. 16.87.

24. Berkout. V. D.: Mazurkiewicz. P.: Deinzer, M. L. J. Am Chent. Soc. 1999. 121. 2561.

25. Arulmozhiraja. S.: Fujii. T.: Tokiwa. H. J. Phns. Ghem. A 2000. 104. 7068 .
26. Frisch. M. J.: Trucks, G. W: Schlegel. H. B.: Scuseria, G. E.: Robb. M. A.; Cheeseman. J. R.: Zakrzewski. V. G.: Montgomery. J. A.. Ir: Stratmant1. R. E.: Burant. T. C.: Dapprich. S.: Millam. T. M.: Daniels. A. D.: Kudin. K. N.: Strain. M. C.: Farkas. O.: Tomasi. T.: Barone. V: Cossi. M.: Cammi. R.: Mennucei. B.: Pomelli. C.: Adamo. C.: Clifford. S.; Ochterski. J:- Petersson, G. A.; Ayala. P. Y; Cui. Q.: Morokuma, K.: Malick. D. K: Rabuck, A. D.: Raghavachari. K.: Foresman. J. B.; Cioslowski, J.: Ortiz, J. V.: Stefanov. B. B.: Liu. G.: Liashenko. A.: Pishorz. P.: Komaromi. I.: Gomperts. R.: Martin. R. L.: Fox. D. T.: Keith. T.: Al-Laham. M. A.: Peng. C. Y.: Nanayakikara. A.: Gonzalez. C.: Challacombe. M: Gill, P. M. W: Johnson. B. G; Chen, W: Wong. M. W: Andres. J. L.: Head-Gordon, M.: Replogle, E. S.; Pople. J. A. Gaussiam 98. Revision A.9: Gaussian. Inc.: Pittsburgh. PA. 2000.

27. Horny. L.: Petraco. N. D. K.: Schaefer. H. F. J. Am. Chem. Soc. 2002. 124.14716 .

28. Richardson. N. A.: Wesolowski. S. S.: Schaefer. H. F. J. Phus. Chent B 2003. 107. 848 .

29. Adriaens. P; Chang. P. R; Barkovskii, A. L. Chemosphene 1996. 32. 433 .

30. Barkorskii. A. L.: Adriaens. P. Appl. Enwon. Mficrobiol 1996. 62.4556 .

31. Adriaens. P.: Fu. Q.: Grbic-Galic. D. Environ. Sci. Techol. 1995. 29. 2252.

32. Konstantinov. A.: Bunce. N. J. J. Phorochem. Phorobiol. A: Chent. 1996. $94,27$.

33. Ohachi. M. O.: Isujimoto. K.: Seki. K. J. C. S. Chem Conm 1973. 389. 384 .

34. Bunce. N. J.: Safe. S.: Ruzo. L. O. J. C. S. Perkin I 1975. 1607. 